\title{
NEW GENERALIZATIONS OF INEQUALITIES OF HARDY AND LEVIN-COCHRAN_LEE TYPE FOR MULTIDIMENSIONAL BALLS
}

\author{
ALEKSANDRA ČIŽMEŠIJA AND JOSIP PEČARIĆ
}

Abstract. This paper deals with some new sharp generalizations of inequalities of Hardy and Levin-Cochran-Lee type for $n$-dimensional balls.

Mathematics subject classification (2000): 26D10, $26 \mathrm{D} 15$.

Key words and phrases: Hardy inequality, Levin-Cochran-Lee inequality, best possible constants.

\section{REFERENCES}

[1] M. Christ and L. Grafakos, Best constants for two nonconvolution inequalities, Proc. Amer. Math. Soc. 123, No. 6 (1995), 1687-1693.

[2] A. ČIŽMEŠIJA AND J. PEČARIĆ, Mixed means and Hardy's inequality, Math. Inequal. Appl. 1, No. 4 (1998), 491-506.

[3] A. ČIŽMEŠIJA, J. PEČARIĆ, AND I. PERIĆ, Mixed means and inequalities of Hardy and Levin-Cochran-Lee type for multidimensional balls, Proc. Amer. Math. Soc. 128, No. 9 (2000), 2543-2552.

[4] A. ČǏ̌MEŠIJA AND J. PEČARIĆ, Classical Hardy's and Carleman's inequalities and mixed means, in: T. M. Rassias (ed.), Survey on Classical Inequalities, Kluwer Academic Publishers, Dordrecht/Boston/London, 2000, p.p. 27-65.

[5] A. ČIŽMEŠIJA AND J. PEČARIĆ, Some new generalisations of inequalities of Hardy and Levin-CochranLee, Bull. Austral. Math. Soc. 63 (2001), 105-113.

[6] P.DRÁBEK, H. P. HEINIG, AND A. KUFNER, Higher dimensional Hardyinequality, Int. Ser. Num. Math. 123 (1997), 3-16.

[7] G. Hardy, J. E. Littlewood, And G. Pólya, Inequalities, 2nd edition, Cambridge University Press, Cambridge, 1967. 